\title{
Interactive comment on "Estimating the degree of preferential flow to drainage in an agricultural clay till field for a 10-year period" by David Nagy et al.
}

\section{David Nagy et al.}

davidnagy@agro.au.dk

Received and published: 13 April 2020

We have addressed and carefully considered the constructive comments/inputs by Reviewer $\backslash \# 1$ and made the suggested revisions and modifications where we find them appropriate. We very much appreciate the extensive review of our manuscript provided. Altogether we believe the manuscript with the modifications has improved with the revisions made and we very much hope that you will consider the revised manuscript for publication. Due to the policy of HESS, the revised manuscript will be not uploaded, until further approval.

Please find the detailed answers in the supplement of this letter. 
Please also note the supplement to this comment:

https://www.hydrol-earth-syst-sci-discuss.net/hess-2019-665/hess-2019-665-AC1-

HESSD

supplement.pdf

Interactive comment on Hydrol. Earth Syst. Sci. Discuss., https://doi.org/10.5194/hess-2019-

665, 2020.

Interactive

comment 